\title{
Variation in ribosomal DNA within and between populations of Isotoma petraea and Macrozamia riedlei
}

\author{
M. BYRNE*, M. WAYCOTT, A. A. HOBBS $+\&$ S. H. JAMES \\ Department of Botany, The University of Western Australia, Nedlands, W.A. 6907, Australia and $\uparrow$ Department of \\ Biochemistry, The University of Western Australia, Nedlands, W.A. 6907, Australia
}

\begin{abstract}
Restriction fragment length polymorphisms in ribosomal DNA were observed within and between populations of Isotoma petraea and Macrozamia riedlei. Isotoma petraea is a diploid self-pollinating species which has evolved complex hybridity in response to inbreeding and exhibits high levels of genetic differentiation between its geographically isolated populations. Macrozamia riedlei is a diploid dioecious wind-pollinated cycad with high levels of gene flow throughout its population system. Variation in rDNA was observed within and between populations of both species. In I. petraea the level of variation was low with most individuals having one length variant, except in populations with fixed hybridity, whereas in $M$. riedlei high levels of variation were observed with an average of eight variants per individual. The pattern of variation in I. petraea showed homogenization of length variants within individuals and populations with divergence of length variants between populations. The pattern of variation in $M$. riedlei showed mixing of length variants and maintenance of various length variants within individuals and populations. The different patterns of variation are consistent with the different breeding systems of the two species.
\end{abstract}

Keywords: diversity, Isotoma petraea, Macrozamia riedlei, rDNA.

\section{Introduction}

Variation in rDNA commonly occurs through differences in the number of gene units or differences in the length of the gene unit. The rRNA gene unit containing the $18 \mathrm{~S}, 5.8 \mathrm{~S}$ and $25 \mathrm{~S}$ genes has been found to be highly conserved between plant species (Appels \& Dvorak, 1982). Most rDNA diversity has been attributed to variation in the rapidly evolving component of the gene unit, the intergenic spacer region. Homogenization of repeated sequences such as rDNA has been observed within species, populations and individuals with divergence of repeats between species (Sytsma \& Schaal, 1990). The rate at which this concerted evolution will occur will be determined by the breeding system and biological context of the species (Dover et al., 1982). Large numbers of studies of isozyme variation in a range of plant species have enabled generalizations about the evolutionary forces and population parameters

${ }^{*}$ Correspondence and present address: Western Australian Herbarium, Department of Conservation and Land Management, Locked Bag 104, Bentley Delivery Centre W.A. 6983, Australia. E-mail: margaretb@calm.wa.gov.au that affect the level and distribution of isozyme variation in plants (Hamrick \& Godt, 1990). Similar studies on rDNA will provide information on the interaction between the generation and homogenization of rDNA and the evolutionary forces that affect the level and distribution of the variation within species (Sytsma \& Schaal, 1990).

Variation in the rRNA gene unit has been observed between natural populations of species and some studies have shown association between rDNA variation and population characteristics. In Lisianthius variation between populations was attributed to genetic drift arising from spatial and genetic isolation between the populations (Sytsma \& Schaal, 1990). Genetic differentiation between populations was also observed in Phlox because of limited gene flow between populations (Schaal et al., 1987). Spatial differentiation of variants was observed within a population of Clematis fremontii indicating population subdivision consistent with limited gene flow within the population (Learn \& Schaal, 1987). Differentiation of rDNA among populations of both Picea rubens and $P$. mariana was attributed to genetic drift or forces related to ecogeographical selection 
(Bobola et al., 1992). Directional selection was responsible for the substantial change in allele frequencies occurring in a population of barley over 53 generations (Saghai-Maroof et al., 1984).

Restriction fragment length polymorphism in the rRNA gene unit in two native Western Australian plants, Isotoma petraea F. Meull. and Macrozamia riedlei (Gaud.) C.A. Gardn., has been investigated. These two species have different life history traits with contrasting breeding systems and levels of gene flow. Isotoma petraea is a herbaceous perennial member of the Lobeliaceae. It is a highly inbreeding species that occurs in geographically isolated populations on granite outcrops in the wheat belt and gold field regions of Western Australia The species has evolved complex hybridity in its most south-western populations (James, 1965) and there is little gene flow between populations in this species because of their geographical isolation and genetic divergence. In contrast $M$. riedle $i$ is a cycad of the family Zamiaceae with a more or less continuous distribution throughout the south-west of Western Australia. It is dioecious, and therefore outbreeding, and windpollinated with high levels of gene flow (Byrne \& James, 1991).

\section{Materials and methods}

\section{Plant material}

Leaf samples were collected of single individuals from 20 populations of $I$. petraea covering the range of the species distribution (Fig. 1). To assess the variation within populations samples from 17 to 20 individuals from four of the populations (Pigeon Rock, Bencubbin, Yellowdine and Three Mile Rock) were also collected. Nineteen $F_{1}$ progeny of a cross between individuals from Pigeon Rock and Yackeyackine populations, and $19 \mathrm{~F}_{2}$ progeny from one of the $F_{1}$ plants were also sampled. Fronds of a single seedling plant of $M$. riedlei from four populations were collected, and newly emerging fronds of 16-19 adult plants were collected from one of these populations and two other populations (Fig. 1).

\section{DNA extraction and hybridization}

DNA was extracted from $200 \mathrm{mg}$ of I. petraea shoot apices and $M$. riedlei seedling fronds essentially by the method of Rogers \& Bendich (1985). Extraction of DNA from adult fronds of $M$. riedlei was according to Byrne et al. (1993). DNA samples were digested with DraI, HindIII, EcoRI or BamHI. Restriction sites in the rRNA gene unit were assessed using single digests of DraI, HindIII, EcoRI and $B c l \mathrm{I}$ and double digests of $\operatorname{Dra\mathrm {I}} / \mathrm{Hin} \mathrm{dIII}$, DraI/ $B c l$ I, and HindIII/BclI on DNA of one individual of I. petraea, and single digests of DraI, HindIII, EcoRI and $B c l$ I on DNA of one individual of $M$. riedlei. The DNA was hybridized with clone pTA250.10, a $1 \mathrm{~kb} \mathrm{TaqI}$ fragment from the 18S rRNA gene of wheat, clone pTA250.3, a $0.9 \mathrm{~kb}$ BamHI/EcoRI fragment from the 26S rRNA gene of wheat (Appels \& Dvorak, 1982), and clone pTA71, containing the entire rRNA gene unit of wheat (Gerlach \& Bedbrook, 1979).

\section{Results}

\section{Restriction site analysis of the rRNA unit}

Hybridization of single digests of $I$. petraea DNA with pTA71 revealed one $10.4 \mathrm{~kb}$ HindIII fragment, two DraI fragments of $8.1 \mathrm{~kb}$ and $2.3 \mathrm{~kb}$, and two EcoRI fragments of $6.9 \mathrm{~kb}$ and $3.5 \mathrm{~kb}$. No discrete

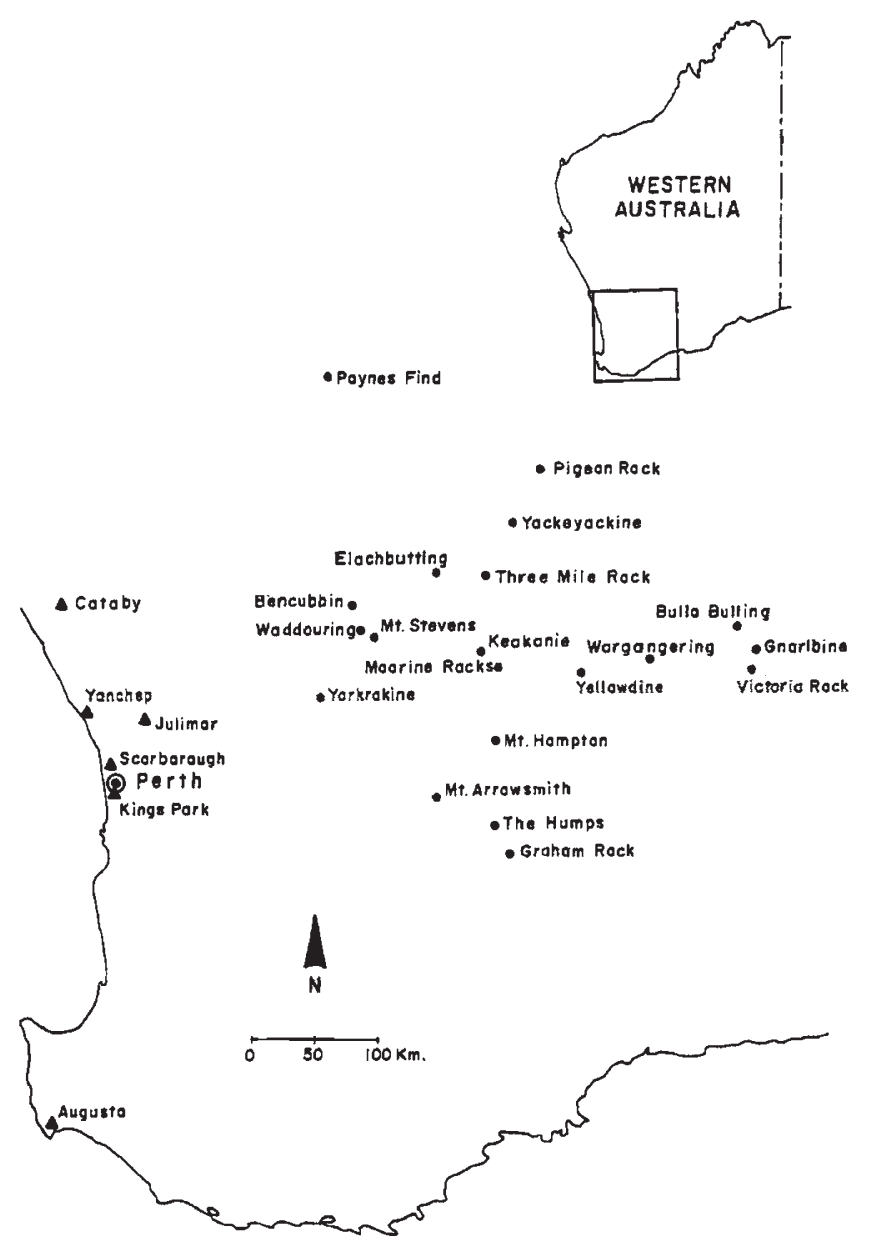

Fig. 1 Location of sampled populations of Isotoma petraea

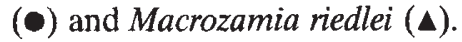


$B c l$ I fragments were identified. Thus the rRNA unit in I. petraea contains one HindIII, two DraI, two $E c o$ RI and no $B c l$ I restriction sites. Double digests with $D r a \mathrm{I} / B c l \mathrm{I}$ and $H i n \mathrm{dIII} / B c l \mathrm{I}$ revealed the same fragments as single digests with DraI and HindIII. Double digests with DraI/HindIII revealed three fragments of $3.4 \mathrm{~kb}, 4.7 \mathrm{~kb}$ and $2.3 \mathrm{~kb}$, indicating that the HindIII site is in the large DraI fragment. Hybridization of the single and double digests with pTA250.3 and pTA250.10 showed that the larger of the DraI and EcoRI fragments contained the 18S gene and the smaller fragments contained the 26S gene. As discussed below no variation was observed with pTA250.3 containing the $26 \mathrm{~S}$ gene and variation in fragment size was observed with pTA250.10 and pTA71 indicating that the variable intergenic spacer is contained in the larger DraI and EcoRI fragments that also contain the $18 \mathrm{~S}$ gene.

The restriction fragment profile of $M$. riedlei was more complex than that of $I$. petraea, with up to 14 fragments revealed in single digests of DraI, HindIII and $E c o$ RI from one individual probed with pTA71. The size of the fragments ranged from 1.9 to $21 \mathrm{~kb}$. No discrete $B c l$ I fragments were observed, indicating no $B c l$ I restriction sites in the $M$. riedlei rRNA gene unit. Hybridization with pTA250.3, containing the 26S gene, showed two fragments in EcoRI digests and three fragments in HindIII and DraI digests. This suggests that in $M$. riedlei the rRNA gene may be present at three loci. Alternatively, restriction site variation may exist in the gene unit.

\section{Ribosomal RNA gene variation in I. petraea}

Hybridization of the 26S (pTA250.3) probe to DNA from all individuals of $I$. petraea showed no variation in any individuals either between or within populations. Hybridization of the probe containing the intergenic spacer to DNA from all individuals showed variation in fragment sizes both within and between populations. Variation between populations was investigated by hybridization of the pTA250.10 probe to DNA from an individual from each of 20 populations of $I$. petraea. Fourteen of the individuals showed a single band corresponding to fragments ranging in size from $8 \mathrm{~kb}$ to $9.4 \mathrm{~kb}$ (Fig. 2.). All the noncomplex hybrid individuals and half of the complex hybrids are represented in this group. Four of the other six individuals showed two length variants (Fig. 2). In these individuals the two fragments either appeared as one strong band and one faint band (lanes 9, 19 and 21) or two bands of similar intensity (lane 14) and were also in the size range of $8-9.4 \mathrm{~kb}$. The remaining two individuals showed three length variants (Fig. 2). One of these individuals showed three bands of $9.4,8.5$ and $8 \mathrm{~kb}$ with one band twice as intense as the other two (lane 7). The other individual showed two bands of similar intensity ( 8 and $9.2 \mathrm{~kb}$ ) and a smaller, less intense band of $2.3 \mathrm{~kb}$ (lane 20 ). The presence of the small band may indicate an additional restriction site in some of the copies of the rRNA gene unit in this individual. The individual with two bands of equal intensity and the three-banded individuals are all complex hybrids with large ring structures. The average number of length variants produced per individual was 1.4.

Variation within populations was investigated in four populations. No variation was observed in the Yellowdine population (noncomplex hybrids) and all 20 plants showed a single band of similar intensity. A similar lack of variation was observed in the

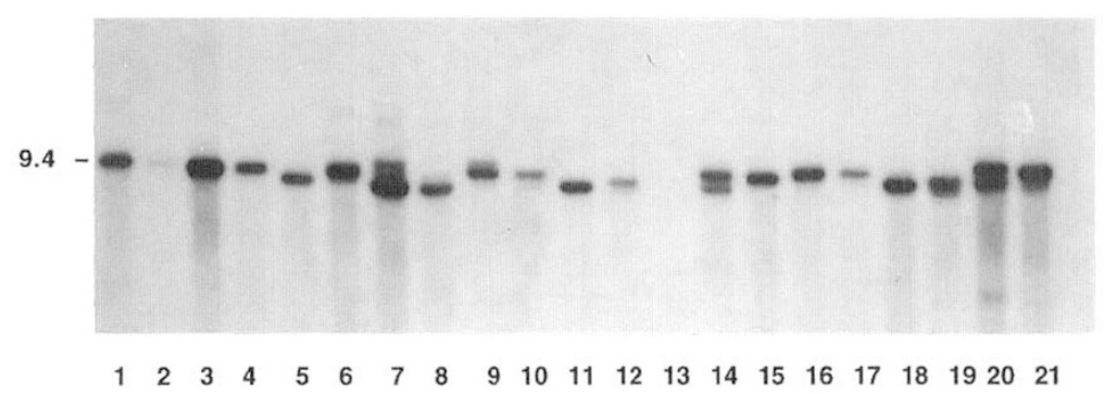

Fig. 2 Variation in rDNA between individuals from 20 populations of Isotoma petraea. DNA was digested with DraI and hybridized with the probe pTA250.3. Lanes 1-21: Yackeyackine, Yellowdine, Victoria Rock, Gnarlbine, Wargangering, Bulla Bulling, Paynes Find, Pigeon Rock, Mt Stevens, The Humps, Keokanie, Mt Hampden, Three Mile Rock, Moorine Rocks, Elachbutting, Graham Rock, Yorkrakine, Waddouring, Bencubbin, Mt Arrowsmith. Lane 13 is blank. Size (kb) given at left. 
Bencubbin population (large ring structure complex hybrids) but with all 17 individuals having two bands of equal intensity. Variation was observed in the Pigeon Rock and Three Mile Rock populations (mixed complex hybrids and noncomplex hybrids). In the Pigeon Rock population all 18 individuals had one band with polymorphism for bands between some individuals. The $8 \mathrm{~kb}$ fragment was present in 14 individuals, two individuals had a $8.3 \mathrm{~kb}$ fragment and two had a fragment of $9.2 \mathrm{~kb}$. In the Three Mile Rock population 10 individuals showed three length variants of sizes $9.0 \mathrm{~kb}, 8.2 \mathrm{~kb}$ and $2.3 \mathrm{~kb}$, four individuals showed the two larger variants, and three individuals showed the $9.0 \mathrm{~kb}$ variant and the $2.3 \mathrm{~kb}$ variant.

The $F_{1}$ hybrids between Pigeon Rock and Yackeyackine showed two length variants, one of which was derived from the Pigeon Rock parent and the other from the Yackeyackine parent. The $F_{2}$ individuals derived from one of the $F_{1}$ plants showed segregation of the two length variants in a 1:2:1 ratio $\left(7: 10: 2, \chi_{2}^{2}=2.71, P=0.1\right)$ as expected in a selfed heterozygote.

\section{Ribosomal RNA gene variation in M. riedlei}

Hybridization of the pTA71 probe to single individuals from four populations of $M$. riedlei (Julimar, Scarborough, Cataby and Kings Park) revealed six restriction fragments of $18.7,8.4,7.2,5.0,4.65$ and $2.87 \mathrm{~kb}$ that were present in all plants. In addition, all individuals showed from one to three other bands (sizes 21.0, 15.5, 7.8, $6.7 \mathrm{~kb}$ ) which showed polymorphism between the individuals (Fig. 3). The average number of bands per individual was 8.25.

Variation within populations was investigated in 17-19 individuals from three populations, Kings Park, Yanchep and Augusta. The same six monomorphic bands observed between populations were also present in all plants from the Kings Park, Yanchep and Augusta populations; however, variation between individuals was observed in the other fragments. The 19 plants from the Augusta population showed polymorphism for the presence of eight other length variants ranging from 7.8 to $21.0 \mathrm{~kb}$. Nine different genotypes were present in the 19 individuals in this population. The 20 individuals from the Kings Park populations showed polymorphism for the presence of six length variants with seven different genotypes observed. In the Yanchep population polymorphism was observed in five length variants with seven different genotypes present. The polymorphic variants also showed differences in band intensity. The eight length vari- ants in the Augusta population encompassed the length variants present in the other populations.

\section{Discussion}

Variation in rDNA was observed within and between populations of both $I$. petraea and $M$. riedle $i$, and the degree of variation differed between the two species. In I. petraea, individuals generally had one or two rRNA gene length variants whereas individuals of $M$. riedlei showed 11-14 length variants. Restriction site analysis of the rDNA shows that $I$. petraea possesses a single rDNA locus and analysis of the inheritance and segregation of variants in an $\mathrm{F}_{2}$ cross of $I$. petraea was consistent with the presence of one locus. In $M$. riedlei the restriction site analysis suggests three rDNA loci may be present. No genetic analysis could be carried out in $M$. riedlei because of the difficulty in making crosses in cycad species. Multiple rRNA gene loci have been observed in several other species (Saghai-Maroof et al., 1984; Sano \& Sano, 1990; Faivre-Rampant et al., 1992; Cluster \& Allard, 1995). The length of the rRNA repeat unit in $I$. petraea is within the range

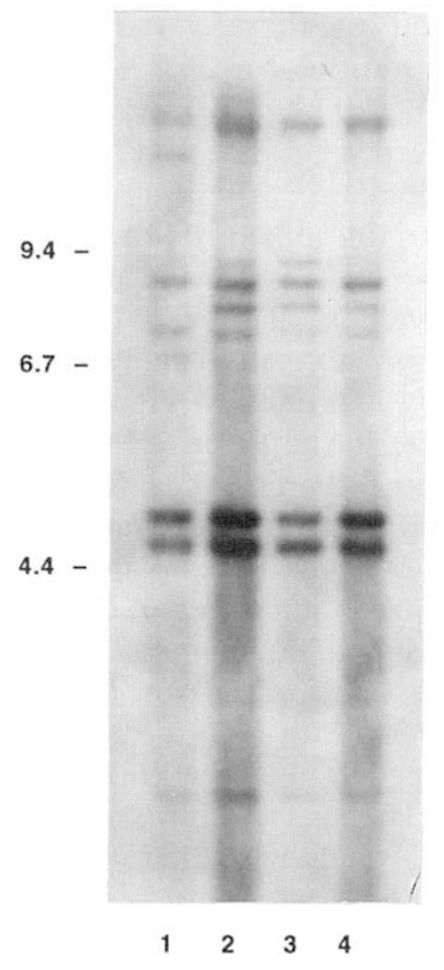

Fig. 3 Variation in rDNA between individuals of four populations of Macrozamia riedlei. DNA was digested with DraI and hybridized with the probe pTA250.3. Lanes 1-4: Cataby, Scarborough, Kings Park, Julimar. Size (kb) given at left. 
that has been determined for other plant species (8.3-18.5 kb, Appels \& Honeycutt, 1986) but the length of the rDNA gene unit in $M$. riedlei $(21 \mathrm{~kb})$ is larger than has been seen in other plants.

In I. petraea, individuals generally possess one major length variant suggesting homogenization of the rRNA gene family to a single length variant in these individuals. All the noncomplex hybrid individuals show a single length variant suggesting complete homogenization of rDNA in these individuals and populations. This is consistent with the high levels of inbreeding and geographical isolation of the populations. It has been proposed that largeringed complex hybridity in I. petraea evolved and spread through the population system by segregational events following interpopulational hybridizations (James, 1970). The generation of two fragments in the Pigeon Rock $\times$ Yackeyackine $F_{1}$ hybrids shows that multiple-banded phenotypes can be generated by crossing individuals from different populations and supports this hypothesis. Most of the complex hybrid populations exhibit one major length variant. The presence of some additional copies of the rRNA gene unit in these individuals is consistent with the hypothesis of hybridization in the evolution of complex hybridity and suggests that homogenization of these variants is in progress. Permanent hybridity for two rRNA gene unit lengths may be achieved if the rRNA gene locus is within the interchanged ring. The lack of variation in the Bencubbin population where all individuals possess two length variants of equal intensity suggests that the rRNA gene locus is within the interchanged ring in these individuals. The variation in the Pigeon Rock population suggests that the autogamous lineages previously identified at Pigeon Rock (James et al., 1990) may be characterized by rDNA variants. Variation in the Three Mile Rock population is consistent with previous observations that this is a young complex hybrid population that has not become stabilized and is characterized by several ring structures and noncomplex hybrids. Thus the pattern of variation in rDNA in I. petraea is consistent with a species with high levels of inbreeding and genetic and geographical isolation of populations and lineages. The species shows strong homogenization of variants which are generated through components of its genetic system.

In $M$. riedlei, individuals possess many variants and extensive polymorphism exists between individuals both within and between populations. Several different variants were present within individuals and polymorphism between individuals and populations occurred because of different patterns of variants present within the individuals. The variation in $M$. riedlei is consistent with an outbreeding species where wind pollination promotes gene flow throughout the population system. Extensive outcrossing of individuals within and between populations results in mixing of the gene unit lengths and maintenance of several unit lengths within individuals and populations. This suggests that the level of gene flow in this species is sufficient to prevent both the homogenization of rDNA variants within individuals and the divergence of rDNA between populations. Similar patterns of multiple rDNA length variants within individuals have been observed in other long-lived outbreeding species: wind-pollinated oaks (Bellarosa et al., 1990) and insect-pollinated rubber trees (Besse et al., 1993).

The level of diversity in rDNA is similar to the diversity observed in isozymes in both species. The level of isozyme variation in I. petraea is low and the complex hybrid populations show higher levels of variation than the noncomplex hybrid populations. However, this variation is generally a result of fixed heterozygosity caused by complex hybridity, and thus the genotype diversity is low (James et al., 1983). High levels of isozyme variation have been observed in $M$. riedle $i$ with 160 multilocus genotypes observed in 174 individuals assayed (Byrne \& James, 1991). The level of diversity in rDNA in $M$. riedlei showed a pattern of increasing variation from the northern population (Yanchep) to the southern population (Augusta). A similar pattern of increasing level of variation was also observed for isozymes (Byrne \& James, 1991). The southern populations are associated with more favourable climatic conditions with cooler temperatures and higher annual rainfall. Associations between rDNA diversity and climatic factors have also been identified in other species. In wild wheat, rDNA diversity and three temperature variables were significantly correlated (Flavell et al., 1986), whereas in oats and barley the distribution of specific rDNA alleles was associated with mesic and xeric conditions (Chalmers et al., 1992; Cluster \& Allard, 1995).

The patterns of diversity in rDNA detected in this study of the two species $I$. petraea and $M$. riedlei are consistent with the differences in their life history traits, their breeding systems and the level of gene flow within the species.

\section{Acknowledgements}

This work was carried out while $\mathbf{M}$. B. held an Australian Postgraduate Research Award. We are grateful to R. Appels for providing the clones

(c) The Genetical Society of Great Britain, Heredity, 79, 578-583. 
pTA250.3 and pTA250.10, and to C. Lanaud for the clone pTA71.

\section{References}

APPELS, R. AND DVORAK, J. 1982. The wheat ribosomal DNA spacer region, its structure and variation in populations and among species. Theor. Appl. Genet., 63, 337-348.

APPELS, R. AND HONEYCUTT, R. L. 1986. rDNA: Evolution over a billion years. In: Dutta, S. K. (ed.) DNA Systematics, vol. 2, pp. 81-135. CRC Press, Boca Raton, FL.

BEllarosa, R., DELRE, V., SCHIRONE, B. AND MAGGINI, F. 1990. Ribosomal RNA genes in Quercus spp. (Fagaceae). Pl. Syst. Evol., 172, 127-139.

Besse, P., Seguin, M., Lebrun, P. AND Lanaud, C. 1993. Ribosomal DNA variation in wild and cultivated rubber tree (Hevea brasiliensis). Genome, 36, 1049-1057.

BOBOLA, M. S., ECKHERT, R. T. AND KLEIN, A. S. 1992. Restriction fragment variation in the nuclear ribosomal DNA repeat unit within and between Picea rubens and Picea mariana. Can. J. Forest Res., 22, 255-263.

BYRNE, M. AND JAMES, s. H. 1991. Genetic diversity in the cycad Macrozamia riedlei. Heredity, 67, 35-39.

BYRNE, M., MORAN, G. F. AND TIBBITS, w. N. 1993. Restriction map and maternal inheritance of chloroplast DNA in Eucalyptus nitens. J. Hered., 84, 218-220.

CHALMERS, K. J., WAUGH, R., WATTERS, J. FORSTER, B. P., NEVO, E., ABBOTT, R. J. AND POWELL, w. 1992. Grain isozyme and ribosomal DNA variability in Hordeum spontaneum populations from Israel. Theor. Appl. Genet., 84, 313-322.

CLUSTER, P. D. AND ALlARD, R. W. 1995. Evolution of ribosomal DNA (rDNA) genetic structure in colonial Californian populations of Avena barbata. Genetics, 139, 941-954.

DOVER, G., BROWN, S., COEN, E., Dallas, J., STRAChaN, T. AND TRICK, M. 1982. The dynamics of genome evolution and species differentiation. In: Dover, G. A. and Flavell, R. B. (eds) Genome Evolution, pp. 342-372. Academic Press, New York.

FAIVRE-RAMPANT, P., JeANDROZ, S., LefEVRE, F., LEMOINE, M., VILLAR, M. AND BERVILLE, A. 1992. Ribosomal DNA studies in poplars, Populus deltoides, $P$. nigra, P. trichocarpa, $P$. maximowiczii, and $P$. alba. Genome, 35, 733-740.
FLAVELl, R. B., O'DELl, M., SHARP, P., NEVO, E. AND BEILES, A. 1986. Variation in the intergenic spacer of ribosomal DNA of wild wheat, Triticum dioccoides, in Israel. Mol. Biol. Evol., 3, 547-558.

GERLACH, W. L. AND BEDBROOK, J. R. 1979. Cloning and characterization of ribosomal RNA genes from wheat and barley. Nucl. Acids Res., 7, 1869-1885.

HAMRICK, J. L. AND GODT, M. J. w. 1990. Allozyme diversity in plant species. In: Brown, A. H. D., Clegg, M. T., Kahler, A. L. and Weir, B. S (eds) Plant Population Genetics, Breeding, and Genetic Resources, pp. 44-64. Sinauer Associates, Sunderland, MA.

JAMES, S. H. 1965. Complex hybridity in Isotoma petraea I. The occurrence of interchange heterozygosity, autogamy and a balanced lethal system. Heredity, 20, 341-353.

JAMES, S. H. 1970. Complex hybridity in Isotoma petraea II. Components and operation of a possible evolutionary mechanism. Heredity, 25, 53-77.

JAMES, S. H., SAMPSON, J. F. AND PLAYFORD, J. 1990. Complex hybridity in Isotoma petraea. VII. Assembly of the genetic system in the $\mathrm{O}_{6}$ Pigeon Rock population. Heredity, 64, 289-295.

JAMES, S. H., WYLIE, A. P., JOHNSON, M. S., CARSTAirs, s. A. AND SIMPSON, G. A. 1983. Complex hybridity in Isotoma petrcea V. Allozyme variation and the pursuit of hybridity. Heredity, 51, 653-663.

LEARN, G. H. AND SCHAAl, B. A. 1987. Population subdivision for ribosomal DNA repeat variants in Clematis fremontii. Evolution, 41, 433-438.

ROGERS, S. O. AND BENDICH, A. J. 1985. Extraction of DNA from milligram amounts of fresh, herbarium and mummified plant tissues. Plant Mol. Biol., 5, 69-76.

SAGHAI-MAROOF, M. A., SOLIMAN, K. M., JORGENSEN, R. A. AND ALLARD, R. W. 1984. Ribosomal DNA spacer-length polymorphisms in barley: Mendelian inheritance, chromosomal location and population dynamics. Proc. Natl. Acad. Sci. U. S. A., 81, 8014-8018.

SANO, Y. AND SANO, R. 1990. Variation of the intergenic spacer region of ribosomal DNA in cultivated and wild rice species. Genome, 33, 209-218.

SCHAAL, B. A., LEVERICH, w. J. AND NIETO-SOTELo, J. 1987. Ribosomal DNA variation in the native plant Phlox divaricata. Mol. Biol. Evol., 4, 611-621.

SYTSMA, K. J. AND SCHAAL, B. A. 1990. Ribosomal DNA variation within and among individuals of Lisianthius (Gentianaceae) populations. Pl. Syst. Evol., 170, 97-106. 